\title{
A CASE STUDY INTO THE SUSTAINABILITY JOURNEY AND BIODIVERSITY CONSERVATION PROJECTS IN SARAWAK BY SARAWAK OIL PALMS BERHAD
}

\author{
JOYCE YIEK LEH CHING*; IVAN CHIRON YAMAN*; KHO LIP KHOON**; CHUA KIAN HONG* \\ and GALAU MELAYONG*
}

\begin{abstract}
Sarawak is the largest state in Malaysia with an oil palm cultivation area of 1.56 million hectares which accounts for $27 \%$ of the total cultivated area in Malaysia. This case study focuses on the sustainability initiatives and outcomes by Sarawak Oil Palms Berhad (SOPB), a Sarawakian oil palms plantation company incorporated in Malaysia. This study shares SOPB's past experiences, present operational practices, its adoption of industry sustainability standards and certification schemes such as the Malaysian Sustainable Palm Oil (MSPO) and International Sustainability and Carbon Certification (ISCC) and SOPB's future plans, in particular, biodiversity conservation efforts while juggling the competing goals of People, Planet and Profit.
\end{abstract}

Keywords: sustainability, certification, conservation, palm oil.

Date received: 19 March 2019; Sent for revision: 17 April 2019; Received in final form: 15 June 2019; Accepted: 26 July 2019.

\section{INTRODUCTION}

Palm oil is known as the most productive oilseed on the global market (Pacheco et al., 2017) and plays a significant role in the consumer goods sector, and as a source of renewable energy used to produce biodiesel (Aruna, 2016). According to Yew et al. (2016), Malaysia has been producing 30\% of edible oil for the global market and is the world's second largest palm oil producer after Indonesia (Norhidayu et al., 2017). Over the years, the palm oil industry has been criticised unceasingly by the non-governmental organisations (NGO) for deforestation, peat destruction and exploitation.

\footnotetext{
Sarawak Oil Palms Berhad, 124-126 Jalan Bendahara, 98000 Miri, Sawarak, Malaysia.

E-mail: sop.sustain-hq@sopb.com.my

** Malaysian Palm Oil Board, 6 Persiaran Institusi,

Bandar Baru Bangi, 43000 Kajang,

Selangor, Malaysia.
}

NGO are campaigning against palm oil and there is growing pressure from Europe to boycott all palm oil imports from Indonesia and Malaysia (Keating, 2019). As such, the need for the oil palm industry to demonstrate sustainable practices and to improve its governance has become the key factor in today's market since the 2000s (Pacheco et al., 2017).

To address the demands for sustainable palm oil, growers are compelled to adopt a combination of standards such as the Roundtable on Sustainable Palm Oil (RSPO), International Sustainability and Carbon Certification (ISCC) or the Malaysian Sustainable Palm Oil (MSPO). RSPO was developed in 2004 to develop and implement global standards for sustainable palm oil. ISCC EU was recognised by the European Commission in 2011 as one of the first sustainability certification schemes in the framework of the Renewable Energy Directive (RED) contributing to the implementation of environmentally, socially and economically sustainable production and use of all 
kinds of biomass in global supply chains before January 2008.

In 2015, MSPO was introduced by the Malaysian government as a national standard committing the country to fulfil sustainability requirements. MSPO is strongly aligned with the existing national legal and regulatory requirements which provide the general principles for the establishment, implementation and improvement of sustainable practices in Malaysia (McInnes, 2017). MSPO will be a mandatory requirement for all Malaysian oil palms industry players by 31 December 2019 (Sivanandam, 2017) providing traceability up to the plantations.

\section{THE EARLY FOUNDATIONS OF SARAWAK OIL PALMS BERHAD (SOPB)}

SOPB was established in 1968 by the Commonwealth Development Corporation (CDC). Our pioneers envisioned that the commercialisation of oil palm cultivation in Sarawak, Malaysia could provide employment to locals and develop talents which would, in turn, spur the growth of smallholders and increase living standards. SOPB has grown steadily and now has an approximate total land bank of 120000 ha with a planted area of 88386 ha (SOPB, 2019a, b). To sustainably manage such large scale operations, there is a need for responsible development, good policies and practices to be integrated into our operations as we believe the protection of our environment is vital to ensure that future generations will continue to benefit from the seeds sown by our pioneers.

During the early years of our development, daily operations were guided by our in-house Agriculture Manual. The use of an Agriculture Manual was to ensure standardised estate operations and it was updated over time and eventually gave rise to the Good Agriculture Practices (GAP) (SOPB, 2017a).

The need for more sustainable practices was emphasised when the Brundtland Commission produced a report in the 1980s defining 'sustainable development' as the development that meets the needs of the present without compromising the ability of future generations to meet their own needs (Brundtland, 1987). Over the past two decades, SOPB has continuously updating the Agriculture Manual to be in line with the latest technological advancements and includes the Best Management Practices (BMP) on peat with reference to RSPO BMP for Existing Oil Palm Cultivation on Peat (Parish, 2013).

\section{THE PRESENT (post-sustainability certification)}

According to a report on 'ESG lessons from palm oil for soy supply chain investors' (Gelder, 2018), oil palm has the highest yield per hectare compared to the other vegetable oils such as soyabean, rapeseed and sunflower. The greatest purposeful challenge for palm oil producers is to continually increase production per unit land area in order to meet the demand by the world's increasing population (Chan, 2005). The international expectations for zero deforestation meant that the oil palm industry is compelled to increase the yield within the existing land area by adopting responsible practices, better technology and demarcate some lands for biodiversity conservation (Sayer et al., 2012).

To meet the requirements of global consumers, SOPB has advanced to formulate sustainability governance (SOPB, 2018) and to develop a framework to promote significant improvements in environmental protection and economic growth of the society at large. To communicate our commitments and progress on sustainability, we rely on certification systems which provide us with a credible way to evaluate our sustainability performance.

SOPB is committed to being fully MSPO certified. We are actively involved in the developing and drafting of MSPO Principles and Criteria as a member of the Technical Working Groups (TWG), Technical Working Committee (TWC) and Expert Working Group (EWG) representing Sarawak Oil Palm Plantation Owners Association (SOPPOA) since the inception of MSPO. Our operational premises are also certified under the ISCC. To date, the entire supply chain of our qualifying upstream and downstream operations has been ISCC certified (SOPB, 2019b) and we aim to complete MSPO certification by September 2019 .

Generally, these sustainability certifications including RSPO, ISCC and MSPO cover requirements such as legality, environmental and social responsibilities, and business practices (McInnes, 2017). This case study describes our approaches to achieve sustainable development as we optimise the needs of People, Planet and Profit.

\section{People}

The social aspect of sustainability focuses on balancing the needs of internal and external stakeholders. In SOPB, we have a comprehensive Corporate Social Responsibility (CSR) programme that seeks to meet the diverse needs of our external stakeholders. We believe that a sincere and longterm CSR programme is a necessary corporate responsibility extended to society beyond our obligation to stockholders or investors in the firm (Nastanski and Baglione, 2014).

SOPB continues to be an active contributor to the local community through various economic support and social contribution programmes. We contribute to the needs of the local communities 
in areas such as education, healthcare and disaster relief. We organise various annual programmes such as Young Achiever Award (YAA), Student Adoption Programme (SAP), Blood Donation Drive and Vision Care Projects for the benefits of the local communities (SOPB, 2010; 2011; 2012; 2013; 2014; 2015; 2016; 2017b; 2018).

As an employer, we aim to be recognised as the employer of choice. We hire, educate and train our employees on the basis of meeting mutual needs and the provision of a healthy, safe and honest working environment. In terms of skills development, in-house training, seminars or workshops are consistently provided to all employees to strengthen their knowledge, productivity and abilities. Training needs assessments and training programmes are formulated for the employee based on their job requirements.

As outlined in our Social and Community Policy and Oil Palms Sustainability Policy, we uphold no discrimination, no forced labour, freedom of engagement, gender equality, protection of children, oppose sexual harassment and provide a healthy and safe workplace for everyone. Our Safety and Health Department was established since the 1990s to carry out mandatory updating of safety procedures and training of competent persons as stated in the Occupational Safety and Health Act 1994 (Department of Occupational Safety and Health, 2018).

With respect to human rights as specified by the Declaration of Human Rights and to protect the rights of our employees and the communities, we have established the relevant policies. In our Social and Community Policy, we declare our commitment to upholding the human rights of our employees and the community around our operations and to treat them with dignity.

In terms of recognition of land rights, SOPB applies the Free, Prior and Informed Consent (FPIC) approach before developing any land which belongs to the indigenous communities by virtue of their legal, communal or customary rights, who account for about $40 \%$ of the local population in Sarawak. To complement the FPIC procedure, we conduct Social Impact Assessments (SIA) concurrently with the Environmental Impact Assessments (EIA).

\section{Profits}

Economic sustainability is achieved by optimising the utilisation of socio-economic resources to their best advantage in a sustainable economic model with equitable distribution and efficient allocation of resources (Basiago, 1999). The efficient and responsible use of those resources provides longterm benefits and establishes profitability. Sustainable profitability for a business means that an organisation provides a service or product that is both profitable, besides being socially and environmentally beneficial (Hammer and Pivo, 2016).

In MSPO, it is stipulated under Principle 6: Best Management Practices that all oil palm growers and millers shall ensure that a proper business management plan is established (Malaysian Standards 2530-3:2013; Malaysian Standards 25304:2013) (Department of Standards, 2018a, b). It is one of the major compliances in the MSPO principle and criteria to demonstrate sustainable business practices. SOPB has consistently reported our financial performances and review the financial reports and budgets each year to ensure that we achieve optimum profits in all our economic activities.

\section{Planet}

With theincreasing global attention and concerns on environmental sustainability, it is imperative that we assess our environmental impacts such as the usage of natural resources, carbon footprint and pollutions. Environmental sustainability in business offers the opportunity to integrate comprehensive sustainability targets and programmes into business strategies and corporate responsibility programmes. More than ever, environmental sustainability is at the forefront of public policy debate (Dickson and Arcodia, 2015) - whether as the focus of innovative scientific research or through local and global policy initiatives such as the Sustainable Development Goals (SDG) and the Paris Agreement (COP22).

As a responsible and ethical company, SOPB puts in place policies and procedures to guide us towards positive actions. Be it through creating a sustainability management team at the operational level, committing to establishing more eco-friendly supply chains, or in developing best practices to reduce harmful or excessive wastes, we lead the movement in environmental sustainability as a corporate citizen to create a sustainable planet, society and economy for future generations.

For instance, in recycling initiatives, every part of the trees are recycled or further processed into byproducts. The fronds are recycled as natural organic fertilisers and act as agent for soil moisture control. The mill by-products such as empty fruit bunches (EFB), bunch ashes, palm oil mill effluent (POME) and decanter cakes are re-applied to the plantations as organic fertilisers. These by-products also act as a natural agent for soil $\mathrm{pH}$ control in the peat soil estate (SOPB, 2017a). The fibres or shells that are extracted from the fresh fruit bunches (FFB) are a source of renewable energy that powers the boilers of the palm oil mill. During replanting programmes, all the old palm trunks are felled, chipped, shredded, mulched and allowed to decompose in situ to improve the fertility of the soil. 
To achieve optimum water level in the estates, several water management practices for peat soil are being practised. For example, water gates, piezometers and subsidence measurement poles are employed to manage and monitor the water flow, avoids excessive subsidence and reduces water stress to the palms. The riparian buffer zones have been established within all our plantations to ensure that a natural 'filter' is in-place to minimise the run-off of chemicals into the natural waterways (SOPB, 2017a).

A significant way to reduce greenhouse gases (GHG) emission is via the installation of biogas plants at our palm oil mills (POM). We have started the installation of our first biogas plant at Metanik POM and we aim to have this implemented in all our POM eventually. For the long-term GHG emission reduction plans, SOPB is collaborating with the Malaysian Palm Oil Board (MPOB) and several universities to determine the GHG emissions in oil palm plantations on peat through various research.

\section{SOPB'S COMMITMENT TO SUSTAINABILITY IN THE FUTURE}

\section{Biodiversity Conservation}

Conservation remains a top priority for SOPB, as we recognise the immense value of biodiversity to the natural surrounding landscape which in turns affects the ecosystem of our oil palms estates.

We are collaborating with local and international partners including universities, research institutions and private companies. A technical advisory committee provides governance and oversight on our research and development programmes. These collaborations facilitate an exchange of knowledge between SOPB and research institutes and enable us to understand better the dynamics of the environment in our estates. With such knowledge, we can improve our estates' management to achieve higher standards, whether on peat or mineral soils and elevate the overall productivity of our existing land bank.

In 2015, SOPB embarked on its journey in conservation through the establishment of a Biodiversity and Conservation Unit. Concurrently, we have signed a collaboration agreement with the MPOB to start a research programme on ecosystem carbon and nitrogen dynamics of tropical peatland in the Sebungan and Sabaju Estates. In 2016, we continue this journey of conservation through the establishment of Tinbarap Conservation Area (TCA) with joint research and conservation study with MPOB and Universiti Malaysia Sarawak in Sarawak (UNIMAS).

The TCA in Beluru is a pioneer project which SOPB has set the stage to conserve and protect biodiversity within its landscape. In TCA, biodiversity studies on trees, birds, mammals, fishes, herpetofauna have been conducted. The survey in TCA recorded 103 species of birds, 10 species of mammals and 13 species of fishes (Amit et al., 2017; Dosi et al., 2017).

In addition to the biodiversity survey at TCA, an in-house carbon stock estimation and monitoring programme of the forested area is also being conducted. On-going studies on carbon fluxes are being conducted in Sebungan and Sabaju Estates by MPOB and post-graduates from both local and international universities, to compare carbon sequestration of oil palm plantation with natural forest. These focus on the carbon stock and the fluxes in the form of carbon dioxide $\left(\mathrm{CO}_{2}\right)$ and methane $\left(\mathrm{CH}_{4}\right)$ in order to promote effective management strategies that optimise yields whilst maintaining the high carbon storage capacity of the soil (Teh et al., 2015; 2017; 2018; Manning et al., 2017; Cook et al., 2017; 2018).

To further enhance the regeneration of our conservation forests, we have initiated a forest rehabilitation, replanting and enrichment programme with Sarawak Forestry Corporation (SFC). Together with SFC and MPOB, a plan has been set into motion to rehabilitate TCA. A nursery has been set up in Tinbarap 5 Estate and native seedlings have been gathered from the forests. These seedlings are nurtured in the nursery until they are matured enough to be replanted in the conservation areas.

SOPB plans to conserve any worthy areas available in our estates. To achieve this, we have engaged MPOB and researchers from several international universities to conduct assistive studies. The future plans for these conservation projects will grow to include bridging the gap between wildlife corridors.

\section{Increase Productivity}

We are developing simulator models to predict the yields of the oil palms that could be a useful tool to improve on our existing operations through increased FFB yield per hectare in our existing land bank.

\section{CONCLUSION - THE WAY FORWARD}

International scrutiny on the oil palm industry will continue to increase over time as new plantations are built over forests. The pressure to produce 'sustainable palm oil' by consumers will inevitably grow. The practical benefits of palm oil must be recognised against the negative narratives carried on international media. SOPB will continue to support all its stakeholders to be MSPO certified as certification is a proven approach to trace and 
improve sustainability practices while balancing the three pillars of People, Planet and Profit (3Ps) (Yunus Yussop, 2019).

There is no silver bullet to end environmental issues. Every nation, every company and every person has a role to play as the world seeks to retain or rejuvenate the natural landscape so that precious species do not head towards extinction. Sustainability is a multi-faceted challenge and one cannot succeed without the participation of all stakeholders including governments, corporates and civil societies. Vicious criticisms without constructive engagements should be avoided. With greater awareness and commitments, we hope that a sustainable future built upon wisdom and truth can prevail.

\section{REFERENCES}

Amit, B; Tuen, A A; Yaman, I C; Harun, $\mathrm{M} \mathrm{H}$ and Kho, L K (2017). Values of conservation area in Tinbarap oil palm plantation, Miri, Sarawak. Poster paper presented at the PIPOC 2017 International Palm Oil Congress and Exhibition. 14-16 November 2017, KLCC, Kuala Lumpur, Malaysia.

Aruna, P (2016). Palm oil on the global stage. https: / www.thestar.com.my / business / businessnews / 2016/12 / 03 / palm-oil-on-the-global-stage/, accessed on 22 May 2019.

Basiago, A (1999). Economic, social, and environmental sustainability in development theory and urban planning practice. The Environmentalist, 19: 145-161.

Borneo Post (2018). Sarawak to enforce MSPO certification for oil palm industry. https://www. theborneopost.com / 2018/08 / 10/ sarawak-toenforce-mspo-certification-for-oil-palm-industry/, accessed on 22 May 2019.

Brundtland Commission (1987). Report of the World Commission on Environment and Development: Our Common Future. Oxford: Oxford University Press. p. 16.

Chan, K W (2005). Best-developed practices and sustainable development of the oil palm industry. J. Oil Palm Res. Vol. 17: 124-135.

Cook, S; Peacock, M; Evans, C D; Page, S E; Whelan, M J; Gauci, V and Kho, L K (2017). Quantifying tropical peatland dissolved organic carbon (DOC) using UV-visible spectroscopy. Elsevier, 115: 229-235.

Cook, S; Whelan, M J; Evans, C D; Gauci, V; Peacock, M; Garnett, M H; Kho, L K; Teh, Y A and Page, S E
(2018). Fluvial organic carbon fluxes from oil palm plantations on tropical peatland. Biogeosciences, 15(24): 7435-7450.

Department of Occupational Safety and Health (2018). Occupational Safety and Health Act 1994 (Malaysia). http://www.dosh.gov.my/index.php/ en / list-of-documents / acts / 23-02-occupationalsafety-and-health-act-1994-act-514/ file>, accessed on 2 December 2018. p. 1-35.

Department of Standards Malaysia (2018a). Malaysian Sustainable Palm Oil (MSPO) Part 3: General Principles for Oil Palm Plantation and Organised Smallholders, MS 2530-3:2013. Accessed on 2 December 2018. p. 1-15.

Department of Standards Malaysia (2018b). Malaysian Sustainable Palm Oil (MSPO) Part 4: General Principles for Palm Mills, MS 2530-4:2013. Accessed on 2 December 2018. p. 1-12.

Dickson, C and Arcodia, C (2015). Environmentally sustainable events: A critical review of the literature. https: / / www.researchgate.net/ publication / 265824784_Environmentally_ sustainable_events_a_critical_review_of_the literature, accessed on 22 May 2019.

Dosi, E M; Tuen, A A; Yaman, I C; Harun, M H and Kho, L K (2017). Fish fauna from conservation area in oil palm plantation on peat. Poster paper presented at the PIPOC 2017 International Palm Oil Congress and Exhibition, 14-16 November 2017, KLCC, Kuala Lumpur, Malaysia.

Gelder, J (2018). ESG lessons from palm oil for soy supply chain investors. How Sustainability Risks Can Become Material. United States: Chain Reaction Research, https://chainreactionresearch.com/ wp-content / uploads / 2018 / 09 / ESG-Lessons-fromPalm-Oil-for-Soy-Supply-Chain-Investors-180911-2. pdf, accessed on 22 May 2019. p. 2.

Hammer, J and Pivo, G (2016). The triple bottom line and sustainable economic development theory and practice. Economic Development Quarterly, 31(1): 25-36.

Keating, D (2019). EU labels biofuel from palm oil as unsustainable, bans subsidies. https: / / www.forbes. com / sites / davekeating / 2019/03/14/ eu-labelsbiofuel-from-palm-oil-as-unsustainable-banssubsidies/, accessed on 22 May 2019.

Manning, F; Kho, L K; Hill, T and Teh, Y A (2017). Methane and $\mathrm{CO}_{2}$ fluxes from peat soil, palm stems and field drains in two oil palm plantations in Sarawak, Borneo, on different tropical peat soil 
types. Proc. of the $19^{\text {th }}$ EGU General Assembly 2017. 2328 April 2017, Vienna, Austria. p. 1660.

McInnes, A (2017). A comparison of leading palm oil certification standards. Forest Peoples Programme. https: / / www.forestpeoples.org / sites / default / files / documents / Palm $\% 20$ Oil $\%$ 20Certification $\% 20$ Standards_lowres_spreads.pdf, accessed on 6 January 2019. p. 12.

Nastanski, M and Baglione, S (2014). Sustainability: Benefits of social responsibility to brand value \& profit. The J. International Management Studies, 9(2): 3.

Norhidayu, A; Nur-Syazwani, M; Radzil, R; Amin, I and Balu, N (2017). The production of crude palm oil in Malaysia. International J. Economics and Management, 11(S3): 591-606. http://www.ijem. upm.edu.my / vol11noS3/(2)\%20IJEM\%20(S3)\%20 $2017 \%$ 20R2\% 20The $\%$ 20Production $\% 20$ of $\% 20$ Crude \%20Palm\%200il\%20in\%20Malaysia.pdf, accessed on 22 May 2019.

Pacheco, P; Gnych, S; Dermawan, A; Komarudin, H and Okarda, B (2017). The Palm Oil Global Value Chain: Implications for Economic Growth and Social and Environmental Sustainability. Working Paper 220. Bogor, Indonesia: CIFOR. p. 10-38.

Parish, F (2012). RSPO Manual on Best Management Practices (BPMPs). RSPO Secratariat. p. 1-154.

Sarawak Oil Palms Berhad (2011). Sarawak Oil Palms Berhad Annual Report 2010: Building a Sustainable Future. http://www.sop.com.my/wp-content/ uploads / 2012/08/annual-report-2010.pdf, accessed on 2 December 2018. p. 19-20.

Sarawak Oil Palms Berhad (2012). Sarawak Oil Palms Berhad Annual Report 2011: Sustainability. http:// www.sop.com.my/wp-content/uploads / 2012/08/ annual-report-2011.pdf, accessed on 2 December 2018. p. 20-21.

Sarawak Oil Palms Berhad (2013). Sarawak Oil Palms Berhad Annual Report 2012: Sustainability. http:// www.sop.com.my/wp-content/uploads / 2012/08/ SOPBAR20121.pdf, accessed on 2 December 2018. p. 20-21.

Sarawak Oil Palms Berhad (2014). Sarawak Oil Palms Berhad Annual Report 2013: Building a Sustainable Future. http://www.sop.com.my/wpcontent/ uploads / 2014/06 / Final-OP-2013-Set-18. compressed.pdf, accessed on 2 December 2018.

Sarawak Oil Palms Berhad (2014). Social and Community Policy. http://www.sopb.com.my/ sustainability / docs / Social-and-Community-Policy. pdf, accessed on 2 December 2018. p. 20-23.
Sarawak Oil Palms Berhad (2015). Sarawak Oil Palms Berhad Annual Report 2014: Building a Sustainable Future. http://www.sop.com.my/wp-content/ uploads / 2015/06/2014-SOP-ANNUAL-REPORT. pdf, accessed on 2 December 2018. p. 20-21.

Sarawak Oil Palms Berhad (2016). Sarawak Oil Palms Berhad Annual Report 2015: Building a Sustainable Future. http://www.sop.com.my/wp-content/ uploads / 2016 / 06/SOPB-Annual-Report-2015.pdf, accessed on 2 December 2018. p. 22-27.

Sarawak Oil Palms Berhad (2017a). Agriculture Manual. SOPB. p. 1-116.

Sarawak Oil Palms Berhad (2017b). Sarawak Oil Palms Berhad Annual Report 2016: Building a Sustainable Future. http://www.sop.com.my/wp-content/ uploads / 2017 / 06/SOPB-AnnualReport-2016.pdf, accessed on 2 December 2018. p. 33-37.

Sarawak Oil Palms Berhad (2018). Sarawak Oil Palms Berhad Annual Report 2017: Building a Sustainable Future. http://www.sop.com.my/wp-content/ uploads/2018/06/AR-2017.pdf, accessed on 2 December 2018. p. 28.

Sarawak Oil Palms Berhad (2019a). Sarawak Oil Palms Berhad Annual Report 2018: Building a Sustainable Future. http://www.sop.com.my/wp-content/ uploads/2019/05/SOP-AR-2018.pdf, accessed on 15 June 2019. p. 16-58.

Sarawak Oil Palms Berhad (2019b). SustainabilityInternational Sustainability and Carbon Certification (ISCC), Sarawak Oil Palms Berhad. http://www. sopb.com.my/sustainability/iscc.php, accessed on 21 May 2018.

Sayer, J; Ghazoul, J; Nelson, $\mathrm{P}$ and Klintuni Boedhihartono, A (2012). Oil palm expansion transforms tropical landscapes and livelihoods. Global Food Security, 1(2):114-119.

Sivanandam, H (2017). MSPO certification mandatory by 2019. The Star Online. https: / www. nst.com.my/news/2017/02/215108/govt-assuresimplementation-mspo-certification-practicalfinancial-aid, accessed on 22 May 2019.

Teh, Y A; Manning, F; Zawawi, N Z; Hill, T; Chocholek, M and Kho, L K (2015). Soil-atmosphere trace gas exchange from tropical oil palm plantations on peat. Proc. of the $17^{\text {th }}$ EGU General Assembly 2015. 12-17 April 2015, Vienna, Austria. p. 10075.

Teh, Y A; Manning, F; Cook, S; Zawawi, N Z; Sii, L W; Hill, T; Page, S; Whelan, M; Evans, C; Gauci, 
V; Chocholek, M and Kho, L K (2017). Carbon stocks and fluxes in managed peatlands in northern Borneo. Proc. of the 19th EGU General Assembly 2017. 23-28 April 2017, Vienna, Austria. p. 16615.

Teh, Y A; Manning, F; Zawawi, N Z; Cook, S; Sii, L W; Hill, T and Kho, L K (2018). Towards a full greenhouse gas balance of managed tropical peatlands in northern Borneo. Proc. of the $20^{\text {th }}$ EGU General Assembly 2018. 4-13 April 2018, Vienna, Austria. p. 17566.
Yew, VWC; Awang Besar, J; Abdul Manaf, A; Ramli, $\mathrm{Z}$ and Nambiappan, B (2016). The sustainability of oil palm industry in Malaysia: A comprehensive review. International J. Economic Perspectives Vol. 10 No. 4: 305-310.

Yunus Yussop (2019). Oil palm smallholders asked to get MSPO certification. https://www. theborneopost.com / 2019/04/05/oil-palmsmallholders-asked-to-get-mspo-certification/, accessed on 22 May 2019. 